\title{
Youth, Mobility and Generations - the Meanings and Impact of Migration and Mobility Experiences on Transitions to Adulthood
}

\author{
EWA KRZAKLEWSKA ${ }^{1}$ \\ Jagiellonian University
}

\begin{abstract}
The article reflects on the role of mobility within transition to adulthood process. It will present the results of research focusing on the transitions to adulthood of representatives of the generation born at the beginning of the 1980s in Poland. This boom generation experienced both the transformation from a communist to a capitalist state, as well as the joyful and hopeful moment of Poland's accession to the EU in 2004. Post-2004, faced with high unemployment, the representatives of this age cohort decided to leave Poland en masse in search of employment opportunities. Based on biographical interviews with young Poles born in the early 1980s and living in Poland, the article reflects upon the meaning of mobility and migration experiences in their young age. What was mobility impact on different transition to adulthood trajectories - employment, family or independent living? How has it affected the concept of adulthood? In the article, the mobility experience will be looked upon through the lenses of theories of youth studies, which is a recent trend in analyzing young people's mobility or migration. The article points to the three meanings of mobility: mobility as an experience of semi-independence, mobility as time to gain adulthood, and mobility as a celebration of youth. As the experience of this cohort is unique in the historical sense, it is also exemplary for the growing importance of mobility in transitions to adulthood.
\end{abstract}

Keywords: mobility, post-accession migration from Poland, transition to adulthood, youth transitions, adulthood, youth, return migrants, generation

\section{Introduction}

This article reflects on the meanings of mobility within youth transitions, as well as on the importance of mobility experiences for the subjective perception of one's adulthood. I explore the location and understandings of the 'being on the move' experi-

\footnotetext{
1 Contact: ewa.krzaklewska@uj.edu.pl
}

Please cite as: Krzaklewska E. (2019), Youth, Mobility and Generations - the Meanings and Impact of Migration and Mobility Experiences on Transitions to Adulthood, "Studia Migracyjne - Przegląd Polonijny", 1 (171): 41-59. DOI: 10.4467/25444972SMPP. 19.002.10252 
ence among other life events, particularly those experienced in young adulthood by Polish women and men.

The article utilizes data from biographical research focusing on the transitions to adulthood among the representatives of the generation born at the beginning of the 1980s in Poland. As such, it aims at strengthening a generational angle in mobility debates (Krzaklewska 2016). This boom generation (sometimes called the Marshall Law generation) experienced both the transformation from a communist to a capitalist state, as well as the joyful and hopeful moment of the accession to the EU. Faced with uncertainty of the labour market and socio-political system transformation, the representatives of this age cohort decided to leave Poland en masse around the time of Poland's EU accession in 2004. Most of those who migrated around the time of the accession believed their stay abroad was temporary and economic in nature. They had no future plan to remain in the migration country (Fihel, Kaczmarczyk, Okólski 2007). This historical exodus of Polish citizens to other European countries with the UK and Germany being the most popular destinations - resulted in about 2 million Polish men and women living abroad in 2011 for longer than 3 months (GUS 2013). Among them, 78\% had stayed abroad for longer than 12 months (GUS 2013). Notably, most of the migrants were young adults - being 25-29 or 30-34 at the moment of the National Census in 2011 - and thus belong to the age cohort born around the early 1980s.

As the studied cohort's experience is unique in the historical sense, it is also exemplary for the growing importance of mobility in transitions to adulthood. The article contributes to the recent debate in youth studies criticizing the "sedentary nature of youth transitions" (Cairns 2014), which until recently had not been concerned much with mobility or migration experiences in analyzing young people's paths to adulthood. I have attempted previously in my research to bring these two conceptual frameworks together (Krzaklewska 2007; 2009; 2013). As I argued already in 2009, "we cannot analyse the contemporary migration flows from new EU countries without taking into consideration the new understandings of adulthood that have come about in post-communist states such as Poland" (Krzaklewska 2009), thus the mobility experience will be analyzed within theories of youth studies. This article shows the benefits of including mobility as an important aspect in researching transitions to adulthood, as well as the advantages of using youth theories to help better understand mobility or migration decisions and processes. Especially the first perspective is now strongly pronounced in the academic debate (Cairns 2014; Roberston, Harris, Baldassar 2014), but also migration scholars started to focus more on youth mobility as a particular phenomenon within the analysed flows (King and Williams 2018; King 2018).

Finally, while many studies are concerned with Polish migration wave around the accession period (see e.g. Eade, Drinkwater, Garapich 2006; Fihel et al. 2007), also in particular young Poles migration (White 2010; Szewczyk 2015; Huang et al. 2016), 


\section{SM̂PP}

much fewer studies concern return migration (e.g. Grabowska-Lusińska 2010; White 2014). This article will present the story of mobility for those young Polish women and men who experienced it rather as an episode or a past phase in their biographies. Nevertheless, as it will be shown, even if it is an important trait of their personal story of becoming an adult, it operates next to a generational story of a cohort entering adulthood in the time of Europe opening its borders for Central-Eastern Europeans, thus creating new chances for experiencing youth and capitalizing on the mobility within transitions to adulthood. This story of opportunity is strongly present in the narratives of the studied generation (Wrzesien 2009; Szewczyk 2015).

\section{Mobility as an integral part of transitions to adulthood}

In European societies, the traditional model of transition to adulthood, a rapid one with most life events co-occurring, has been substituted by the postmodern model in which youth transitions are usually prolonged, fragmented and individualized (Galland 1996; Shanahan 2010). Until recently, and based on the life-course perspective, youth transitions studies concentrated on the analysis of five main transitions: completing education, assuring employment, independent living, creating a relationship/ marriage and having children (Billari 2001; Settersten 2007). Mobility has tended not to have been included in those analytical models and only in the last few years it was suggested that mobility transitions or episodes should also be studied within this framework, recognizing the intense engagement of young people in international movement (e.g. Cairns 2014; Roberston, Harris, Baldasar 2018; King 2018). The 'mobility turn' contributed to the debate on youth transition framework, ultimately seeing the classic, linear one as limited and normative, thus exclusionary, not mirroring well the complexity of youth's pathways today within their spatial dimension.

Reflexivity is demanded from young people who need to navigate between existing opportunities in relation to their own dreams and plans (Heinz 2009), and the geographical aspect of this process also brings mobility opportunities into the equation. Scholars from youth studies have proposed concepts - with most telling being that of spatial reflexivity (Cairns 2014) - to remind us of the importance of considering mobility and migration experiences in the patchwork of life choices made by young adults. What David Cairns stresses (2014), is not only the importance of considering mobility as a critical dimension in youth decision making, but to keep in mind that migration or mobility are choices that lead to differentiated life outcomes, supporting, hindering or altering youth transitions.

As with all other transitions or life choices, mobility or migration is also limited by particular resources - be they economic, social, linguistic or educational. The mobilization of individual agency or the potential of one's choices is bounded by the structural opportunities available (Furlong, Cartmel 2007; Shanahan 2010). This embeddedness 
of mobility choices in opportunity structures is also clearly discernible in the studied migration wave, which accompanied the accession of Poland to the EU. Specifically, the migrants were actually better educated than a general population, with $23 \%$ of those having completed higher education (GUS 2013). Migration or mobility opportunities were accessible to those with higher social and cultural capital (Slany, Solga 2014). As Cairns, Growiec and Smyth (2012) have argued "moving abroad can offer a path to success or a route away from disadvantage for young people in a peripheral society, for example, the risk of being unemployed or under-employed". Others have suggested that even an imagined mobility, or the geographically-open imaginarium of potential choices, can be seen as an element of youth agency (Cuzzocrea, Mandich 2015).

\section{Methodology}

The research was conducted in 2010-2011 and 37 biographical interviews were completed with 18 men and 19 women who had higher education, were around 30-years-old and were from two big cities - one located in the southern part of Poland and one in the northwest. The study participants were born around the beginning of the $1980 s^{2}$ and at the moment of the research they were between 26 and34 years-old. The aim of the sampling was to find individuals "on their way to adulthood" who were potentially negotiating the traditional constructs of adulthood and creating new models of youth transitions. Therefore, the participants had not concluded all the transitions to adulthood, and in most cases self-identified as "almost adults", being aware of the social expectations towards their "uncompleted" transitions. For example, they lived with their parents, were unemployed, cohabited with a partner and had not married. Each interview started with an invitation to supply a narrative about one's transition to adulthood, as well as about one's youth. The interviews were analyzed using matrices, which were coded with QDAMiner software (Miles, Hubermann 2004).

From the perspective of this article, it is important to mention that a specific experience of mobility was shared across this sample. The study sample consists of young people living in Poland at the time of the interview, but most of them have had mobility or migration experience during young adulthood (usually between 18-30 years of age). They had mostly "returned" from their migration (aside from one respondent who was doing voluntary service abroad). In their accounts, migration or mobility

2 The members of this boom generation, called the boom of the Solidarity period (or Martial Law boom) were born between 1980-1985. In 1980, more than 700,000 children were born, while in 1983 the highest number of births was registered - 723,699 (e.g. compared to 413,300 in 2010). It is argued that this was caused by the newly introduced family policy instruments by Edward Gierek as well as internal migrations within Poland. 


\section{SM̂PP}

were presented typically as a "concluded" (at least for the time being) experience, even if for some of them it had lasted for some years. It was also an experience of those who were in most cases not economically forced to migrate due to a lack of financial resources, which is the case with many migrants. Instead, they rather chose to go abroad for some time (Eade et al. 2006; White 2010). As a result, their motivation can rather be explained through 'pull' factors. The experience of this sample points to the importance of mobility in transitions to adulthood of those with relatively high social capital.

\section{Youth transitions in Poland at the beginning of the $21^{\text {st }}$ century}

The studied generation, entering adulthood at the beginning of the 2000s, is one that prolonged the transitions to adulthood and created new models of transitions that redefined the existing concept of adulthood (Krzaklewska 2016). For this cohort, certain demographic and social processes became evident. First of all, we witnessed the mass participation in tertiary education - in 2010, almost two million students attended higher education institutions (GUS 2010) and there was an extension of the time spent in education. In 2012,39\% of those aged 30-34 in Poland had completed higher education (Eurostat 2012). The pathways to work were particularly fraught for those born at the beginning of the 1980s and their entrance to the labor market at the beginning of the 2000s resulted in high unemployment - the supply of workers was very high and the labor market could not absorb so many young workers, including those with higher education (Desperak, Śmiałek 2010). The young workers were faced with precarious labor market conditions, with almost the highest share of temporary contracts with young employees in Europe (61\% in 2004, Eurostat 2012, Dashboard on Youth Indicators). Migration thus became the main tool for those who could not find their place in the labor market (Grabowska-Lusińska, Okólski 2009). Intensive investments in the construction of one's work history resulted in the frequent participation of young people in unpaid work opportunities - such as internships or voluntary service, as well as diverse forms of learning (workshops, courses, trainings). Having experience of work or an internship abroad was also considered a valuable asset in one's CV (it will be shown as well in the study results). Young Poles also had the possibility to participate in educational opportunities provided by the European Union. Between 1998 and 2011, more than 100,000 students participated in Erasmus exchanges for university students (FRSE 2012). Witold Wrzesień calls this generation "innovators" in relation to the strategies of searching employment abroad and their investments into gathering cultural capital abroad through stipends or internships (2009: 60-61). As research from that period shows, 13\% of young Poles were abroad for educational reasons and $29 \%$ for work, voluntary service 
or other reasons different than tourism (Eurobarometer 2007). Importantly, this generation also experienced the financial and economic crisis of 2008, which created a worsening of the labor market situation, also in foreign countries, and caused a decline in positive evaluation of European integration.

Family transitions were also postponed or even absent from the life-course. For this cohort, researchers have observed a decline in the number of unions concurrent with postponing the time of marriage, as well as having children (Kotowska et al. 2008; Okólski, Fihel 2012). As Krystyna Slany diagnosed (2002, 2007), this younger generation negotiated existing family norms while retreating from the traditional model of the family, frequently choosing cohabitation over marriage. It is importantly to note that in 2010 (GUS 2011), 21\% of children were born out of wedlock. The late timing of family formation is matched by the extension of time spent in the family home (Piszczatowska-Oleksiewicz 2014; Krzaklewska 2017). About half of the young people between 18-35 lived with their parents in 2010 (Choroszewicz, Wolf 2010: after Szafraniec 2011). The representatives of this cohort lived with their parents for an extended period of time - women leave on average when they are 28.5 years-old, while the figure is 29.5 for men (ibidem).

Three main models of transitions were identified within the studied sample of highly educated young people living in the two cities, who were recruited on the basis of their uncompleted pathways to adulthood (Krzaklewska 2016). First, the model of prolonged entrance to adulthood was realized by men and women who were aiming at the realization of five traditional adulthood transitions (completing education, finding employment, getting married/cohabiting, having children, leaving parental home), but structural conditions and personal circumstances hindered the realization of some of these. Those young people usually negatively evaluated their pathway to adulthood, describing themselves as "delayed" and complaining about the living conditions of young generation in Poland. Youth for them is just a 'blink', a short period of life usually associated with the time of being a student, sometimes accompanied by an experience of going abroad.

The second identified model - adulthood anticipated by a phase of youth - reassembles 'emerging adulthood' model by Jeffrey J. Arnett (2004). In this vision of the life-course, adulthood is preceded by a phase of life called youth (in Polish: mtodość). While adulthood occurs with family transitions (forming a family and having children), youth is a period of exploration and sampling opportunities. Youth is fun, with spontaneity and no planning. It is full of parties, education, and - notably - mobility (of a diverse character to that of short migration experiences to extensive travelling). Most of the representatives of this model were still in the phase of youth, taking the opportunity to do things they would not have time to do when they created a family.

The third model - which I term the individualized model of transition - concerned those young people who managed to attain financial and residential independence from their parents. While not having completed family transitions, they nevertheless 


\section{SM̂PP}

considered themselves as 'adults' based on the independence factor. Their pathways are diverse and they believe in the importance of "your own rhythm" in life. Youth experiences, including those of mobility and migration, are to be realized at different moments of life and they are not bound to one life-phase.

\section{Research results}

\section{Mobility as a generational experience}

While mobility experiences were not a criterion for inclusion in the sample, it is notable that twenty of the research participants had some mobility or migration experience during their young adulthood years and voluntarily mentioned it as important while describing their transition to adulthood. But even those who did not go abroad for reasons other than tourism explained why they did not choose mobility. They either described how it did not fit their pathway/career decisions or expressed regret at not making such a decision (this will be discussed later on).

Going abroad for an extended period of time for reasons other than tourism is an event in one's life-course that is drawn into the map of transitions occurring in this life-period. It is intertwined with other transitions, impeding or speeding up certain life decisions, such as cohabitation, having children or leaving the parental home. The mobility experience was not only common in the studied group, but for many of the participants mobility was a particular generational experience (Fihel et al. 2007; Szewczyk 2015).

I just went to England, as many other young Poles did...

\section{After your studies?}

Yes, simply... no, no... wait! I went during my studies, when I broke up with my boyfriend, with whom I was in a relationship during my university years. I needed a change so to leave was the way! n14, F, 29yo

We decided to go to England during the holidays to work. It was very much in fashion back then. And everybody was just going abroad, half to get money from work, half to have an adventure. So, then, we went as well. n20, F, 28yo

The study participants stressed that going abroad was a distinguishing trait for their generation - they underlined its popularity, that it was typical, being amongst the many who also went, and some voiced a feeling of almost feeling pressured in that everyone should take this opportunity. Szewczyk's study (2015) with migrants in the UK shows as well that this identification is very strong for the Poles living abroad.

${ }^{3}$ The codes indicate: the number of the interview, gender (female or male) and age of a research participant. 
The back-then new opportunity to leave the country and work legally abroad emerged in relation to the EU accession and usually coincided with other motivations - such as a relationship breaking down, becoming unemployed or finishing studies. While other European countries were added to the pool of potential localities where one could study, work and live, the imaginatorium of potential futures now included mobility options. There was a generally very positive evaluation of such decisions going abroad was perceived as great in itself and those who crossed the borders were "the successful ones".

\section{Going abroad as a rite of passage? - the experience of semi-independence}

Some of the participants mentioned the moment of going abroad for the first time as the moment when they felt like adults for the first time. It was described as a moment of feeling grown-up, feeling autonomous, of being able to manage by yourself even in crisis situations. Similar accounts have been found in research on Erasmus program participants and especially concerned those who lived away from their parental homes for the first time (Krzaklewska 2013). Young people felt independent, needing to take responsibility for their own actions and were cut off from their obvious support networks. The study participants underlined the realization that they were able to manage by themselves - an important process of maturation, gaining diverse competences, and having an accompanying awareness of it.

I do not regret going to England, because it was a great experience... Really, you are suddenly on your own, you can only rely on yourself, no help from the outside that you would have at home... You go to a doctor... manage with a foreign language... You set up a bank account. With such things I had always turned to my mother, or to my aunt... you know who to ask for help. And here, you get a formal letter, or need to solve some issue and you are alone with it. n14, F, 29yo

O: I went abroad to Brno or to Germany, but in general close to home [laughter]. Maybe I can distance myself but not too much? I liked to live by myself. And then in London, where I went for the whole holiday period, I understood that this is OK, I can manage. It was a real survival. You had no money, no apartment, no work. This gives a lot of emotions and teaches you how to manage. (...) so I have those stages. Stages of realizing I can manage by myself. n10, F, 30yo

This notion of feeling like an adult for the first time when abroad is connected in the case of the studied generation to the context of prolonged permanent residence in the family house and being in education for an extended time. Both of these social situations, living with parents or learning, are rather assigned to nonadults (Krzaklewska 2010). Therefore, for those young people who might be even up to 30 years of age, situations when they were living independently or earning 


\section{SM̂PP}

enough money to support themselves, gave them a particular feeling of autonomy. Another important case relates to cohabitation or living with partners without marriage. For most of the parents of the studied age cohort, cohabitation was regarded as unacceptable (ibidem). While marriage decisions - as seen in the demographic statistics - were not eagerly undertaken, parents were reluctant to financially support cohabitation (or even allow adult children to have a partner sleep over at the family house). Therefore, living abroad gave some of the respondents the possibility to try out this part of the prospective family life. Interestingly, cohabitation abroad did not meet such resistance from parents but was rather seen as an economic solution to housing. Such a story is related by a female participant, recalling her first time living with a boyfriend - she called it a "little life with each other". Notably, she was aware of the actual semi-independence from her parents who sponsored the stay abroad.

\section{R: So do I understand correctly that in England you had the opportunity to live together?}

Yes, and it was a very important moment, because before we had never even slept together overnight in one house. (...) and then 2.5 months of common matters. And shared money, shared planning of expenditures, so kind of a little life together. (...) you are independent. We felt what is a responsibility over your own time, your duties, money we had (...) but... you know... concerning finances, parents were helping us. We were studying not working, so someone had to pay for an apartment and all this. $n 20, F, 28 y 0$

I went for a scholarship (...) for two months (...) with my girlfriend (...) it was a change of environment, I was there with my girlfriend so it was like a 'snapshot' of the life that I wanted to have. A foreign country, more responsibility, you get some money which is limited, parents are not there in case anything goes wrong. So, for sure, even if from the time perspective it seems a bit banal. But it seems banal to me now. n13, M, 29yo

In the male account above, the notion of 'snapshot' of a real life is very telling. From the time perspective, he sees the value of this experience but also a certain naivety in his former evaluation of it. The strong feeling of being an adult for the first time found in the research on Erasmus students (Krzaklewska 2013) does not appear in the biographical accounts of those who are now around 30. The distance that they took from this experience makes lived events rather fit into a series or set of diverse moments or situations that constituted their autonomy. Nevertheless, they mention it as an important stepping stone, potentially speeding up the related life decisions. One could conclude that migration in most cases did not constitute a rite of passage for this group of respondents in its full meaning but rather gave them the opportunity to try out 'adult' life situations - earning money, living independently, cohabiting. They recognize the situation of semi-independence from their parents who often supported their travel abroad or were helping them at home. 


\section{Migration as a time to gain adulthood - gathering important resources abroad}

While mobility was seen in the previous subchapter as an important moment of feeling fully autonomous or independent or somehow in a situation where adult life could be tried out, a share of respondents saw mobility or short-term migration as a space to gather resources for transitions to adulthood. The group that underlined the instrumental role of migration in transition to adulthood are those who paid more attention to the importance of economic independence from their parents. It could also be linked to situations in which parents were unable or had difficulties in supporting their adult children. Migration was directed at earning money to pay for studying, to be able to sustain oneself, living separately from parents or buy an apartment. This fits the most common reason for going abroad, namely the economic one, but also to the characteristic of this generation - as claimed by Krystyna Szafraniec - a generation of ambition (2010). She stated that not many of these young people could be regarded as minimalists but were rather ambitious, overly ambitious or even dreamers - unrealistically trying to reach higher goals. This awareness of being ready to push, to try out more, to prove oneself, is noted in the accounts of migration which could be used to improve one's educational level or economic status, as well as even the social prestige of those who were "brave enough to dare".

\section{R: How long did you stay in Ireland?}

9 months. This is a short period, but it allowed me to save quite a lot of money, which later allowed me to study, and invest a bit. So for two years of my studies, I could unburden my parents almost fully. n29, M, 27yo

I was 20. I had finished the army, and I went to work abroad to Ireland. I was starting to be an adult then. Before you know, a typical guy, parties [...] being crazy. [...] my ideal was to earn money and save as much as possible, and come back and create. [...] I earned some money abroad. So I decided to go to study to show my parents that I can do it and I can be better and better. I did not want to be a physical worker - I know I can do better. n26, M, 27yo

O: I went to England. Regular physical work in a factory. [...] for 2 months. And 2.5 months was enough to bring money for paying for postgraduate studies. So this is important capital. I put it all into education. $n 3, M, 25 y o$

While economic capital appears to play a crucial role in the narratives of migration, other types of capital beyond the economic one were also claimed to have been gathered abroad. This entailed - educational, cultural and social capitals. Time abroad was seen as an important time of learning and an experiential investment in one's prospective career. As mentioned previously, the labor market was difficult for this generation, demanding a lot of investment in one's future career without any 
security that it would pay off. Many skills were perceived as valuable: knowing foreign languages, ability to manage life in a foreign country, intercultural skills, international social networks (cf. Krzaklewska 2010).

From the perspective of youth theories, the period of youth is seen as a time of exploration. Jeffrey Arnett (2004) conceptualized 'emerging adulthood' as the time between being 25 and 30 years old when one's efforts concentrate on exploration in work and love. The mobility experience would thus create additional space for labor market or educational exploration. Certainly, the diverse experience of studying abroad, doing internships or voluntary service abroad plays into this narration. As the new labor market demands were obscure for some parents, this potentially created some generational conflicts:

My parents were not happy that I went for the Erasmus. It was not from the fact that I was abroad, but they just do not understand... they do not get this, that it will be useful for me, learning a language, for my CV, gaining a new level of independence, managing by myself. 8, F, 28

But in the study participants' accounts, there is also a negative side to mobility, often linked to precarity. As mentioned above, this generation of young people needed to invest considerable effort in gathering education capital of diverse kinds, often through unpaid work experience. This resulted in a prolonged permanence of being outside the labor market or being within it but doing precarious work- low or unpaid, with no contract or in the form of an internship or a placement. Mobility and migrational experiences also usually located those young people in worse positions in the labor market, in low-paid jobs, internships, short-term contracts. For some, adulthood is actually the conclusion of mobility and being able to settle down with a permanent work contract in the desired work position in Poland.

\section{Mobility as a celebration of youth}

Mobility is seen as belonging to the 'youth' phase of life, which means that mobility is possible for those who do not have families or strong ties and this can even be seen as an emanation of what it means to be young in Europe (cf. Cairns et al 2018: 93). This was witnessed especially in the accounts of the group who realized the second model of transition, underlining the importance of the celebration of youth. Many participants had mobility experiences such as an Erasmus study period abroad, voluntary service or an internship in another country, or short-term migration e.g. during summer. Those experiences of mobility were mostly remembered as periods of light-heartedness, jauntiness, easiness, freedom, joy. They were frequently linked to educational experiences - most particularly to participation in the Erasmus exchanges between universities. As stated in my previous research on Erasmus 
students, educational mobility was valued by young adults especially because it allowed them to fulfill two demands faced by young people today - that of celebrating youth and investing in the future (through learning, gaining employment experiences; Krzaklewska 2010; 2013).

\section{R: How was your stay in England?}

Loads of fun! I was lucky (...) I had my apartment easily arranged [through a friend], living with Polish girls so I felt at home... We had a great time living together [laughter], so very well, happily, without worries... I always thought I was coming back to Krakow.... So, we earned very good money, we lived in our nice apartment, went shopping, drank coffee... it was a very good time.n15, F, 27yo

O: I worked making strawberry milkshakes (...) going to festivals and thus being in many interesting places, and it was nice but I did not earn enough to bring money home. (...) I always went to England to rather earn experience than money... I was thinking: wow, there is so much ahead of me! (...) it was important that it is summer, and I partied a lot, met a lot of new people, and concentrated on having fun rather than working and earning good money. n5, F, 28yo

Erasmus - I was very satisfied. I love international circles. I love this atmosphere, exchanging thoughts, how they do things, how I do it. (...) at university, in Erasmus, in students organizations... there is more passion and support and how to say... love? (...) at work you feel lonely (...) you do not feel such energy... intense, youth, youthful...n8, F, 28yo

Excessive mobility and movement is also seen in contradiction to adulthood, which is linked to settlement, being rooted in one place, setting up a household, as well as in many cultures - Poland included - to buying an apartment or a house. Spontaneity in movement is a characteristic of youthfulness and growing up was linked to the impossibility of undertaking some mobility decisions, such as an immediate change of the city of residence. As research on Erasmus students showed, a stay abroad can be seen as a "last hurrah" before entering professional life (cf. Cairns et al 2018: 95).

The older you get, the more you get in terms of the fact that you cannot change your path in any moment, but you need to hold to the way you have undertaken, and you cannot just leave it all and go, let's say, for one year to study in Australia. n14, F, 29yo

I had sister in England. She met an English guy in Poland and they moved there. I went to visit then to find student work, to have some fun and practice some English. (...) there was not a moment I needed to take a decision to stay. This was happening. I was young and I was not thinking...about consequences, I would "go with the flow"... no dilemmas. n6, F, $29 y 0$

The strong connection between mobility and youth is easily observable in the ac- 


\section{SM̂PP}

an experience to remember. In the first citation below, the regret of the young woman is directed at certain idealized type of mobility linked to self-observation, free movement and learning about oneself. She is actually still open to such an opportunity as she does not have a partner and believes she could still use this type of experience:

I regret a bit that I did not have such a time after my studies. Some people do it, that after completing their studies they go off on a crazy exploration. Or make a journey.... (...) I did not go too far away.... (...) going to England to earn money, I did not do it... I regret this a little, that I missed some good experiences, but there are some good programs [I could use], or internship programs... I am a single woman (...) why not go on such a work placement.... (....) that could be a great experience. n21, F, 28yo

The feeling of having lost a chance to live out an important experience was also voiced by another study participant, a young man. He stressed that the period of youth is when memories are collected - the norm of "making a good use out of youth" was voiced by those young adults representing the model of adulthood anticipated by youth (or emerging adulthood) (Krzaklewska 2016). This resembles the attitude of "you are only young once" (Ravert 2009), the social demand to gather particular type of experiences during college years.

I would have gone for Erasmus. Or, now I am thinking, I could go to study in Australia for a year. You know, the period of youth, this is a period to collect memories. (...) In your rocking chair you will be saying, when I was 20..., this and that. (...) I would like to have gathered more such memories. I do not say my life is not to intense, but it could be more. (...) this is the biggest regret I have, that I did not use such opportunity. $n 25, M, 27 y o$

Finally, I would like to make a note on the fourth model of adulthood which appears in the study, one characterized by a certain detachment from a locality or a state of being de-rooted - I called it a 'mobile adulthood'. Among my respondents. there was a young woman who I could categorize as a fluid migrant - unpredictable in terms of her choice of location and with changing motivations, not aiming at settling down (Grabowska-Lusińska, Okólski 2009). She wanted to continue to learn, to gather experiences in diverse parts of Europe, she had no precise plans. Her lack of attachment to a place created conflict situations with her mother, for whom the settled character of adulthood was key. The profession of the mother (a dentist) symbolically denotes stability linked to a place and good economic status. The respondent redefined her identity in contrast to it - arguing that adulthood is not settlement but rather means choosing your own path, which for her would be a very mobile one.

I know what my mother would want for me (...) stability in one place, for the whole life, so I would get married, have a child (...), good job, so would stop moving. And for me to 
study, as diplomas are very important for her. (...) I try to explain to my mother that (...) some like such a lifestyle. (...) Perhaps I need to go somewhere still, I need to go and do something, to find myself. (...) I do not know, maybe I will be always on the move, maybe not, as this is a bit tiring... but I do not want to be a dentist... like my mother. n6, F, 29yo

And while recent studies on migration suggest that the fluid migration model may be transforming into more settlement-directed forms of migration, or search of new forms of embedding (Ryan 2018) - there are still young people who do not include in their concepts of adulthood the desire of settlement or rootedness. Their pathways to autonomy are constructed by movement and volatility of connections, in a strong relation to constant search and ongoing (spatial) reflexivity.

\section{Conclusions: mobility and transitions to adulthood}

In this article, I have shown the generational experience of mobility for the cohort born at the beginning of the 1980s in Poland (Krzaklewska 2016; comp. Fihel, Kaczmarczyk, Okólski 2007; Szewczyk 2015). It was very common to go abroad for some time, and mobility and migration choices were predominantly positively valued seen as a 'solution' to personal and structural challenges. The post-accession migration gave young Poles the space to enact their agency when opportunity structures were not available for them in their home country, especially in relation to the situation in the labour market characterized by high unemployment and precarious work conditions. Szewczyk (2015) sees the experience of uncertainty of this generation as a basis for their migration choices. The results indicated that in the studied group mobility was a social expectation young adults had in relation to both the youth lifestyles, where mobility fitted very well in allowing an extensive exploration in the situation of semi-independency, and to the work trajectories - preparing young people to working life, allowing them to have important labour market experiences and developing competences, including foreign language fluency (migration as a time to gain adulthood). Young Poles also invested time in the celebration of youth since mobility was seen as a space for freedom, allowing fun and extensive exploration of a new culture.

Particular meaning of experiences of mobility appear to be characteristic of those realizing certain patterns of transitions to adulthood (Table 1). First, those who prolonged their transitions usually describe mobility as a step in their path to adulthood. Their experiences abroad were rather short and characterized by semiindependence. Second, those who perceived the importance of the youth phase in their life-course aimed at celebrating their youth abroad. Third, those who realized an individualized model of transition exploited their stay instrumentally in order to accumulate important resources and see this experience as a way to achieve or gain adulthood. 
Summarizing those different attitudes, mobility has been described by the young people as supporting a realization of diverse aims, also those linked to adulthood transitions - either in their achievement or postponement. It is important to see those experiences of stays abroad as the ones described from the perspective of time (the interview took place when respondents were about 30 and their stays abroad happen at different times of their young adulthood), which may be the reason for rationalization of their aims and effects from the perspective of the subsequent lifecourse events. The spatial dimension is important in the negotiations of mobility experiences' meanings within one's biography, but it is accompanied by a temporal realm - the distance from the experience also maneuvers the meanings and value.

Table 1.

\begin{tabular}{|l|l|l|}
\hline $\begin{array}{c}\text { Patterns of transition } \\
\text { to adulthood } \\
\text { (Krzaklewska 2016) }\end{array}$ & \multicolumn{1}{|c|}{ Meanings of mobility } & \multicolumn{1}{|c|}{$\begin{array}{c}\text { Effect on youth } \\
\text { transitions' timing }\end{array}$} \\
\hline $\begin{array}{l}\text { Prolonged transition } \\
\text { to adulthood }\end{array}$ & $\begin{array}{l}\text { Migration/mobility as an experience } \\
\text { of semi-independence } \\
\text { - mobility as a step on a pathway } \\
\text { to adulthood }\end{array}$ & $\begin{array}{l}\text { Little effect } \\
\text { or potentially } \\
\text { speeding up }\end{array}$ \\
\hline $\begin{array}{l}\text { Adulthood anticipated } \\
\text { by a phase of youth } \\
\text { (emerging adulthood) }\end{array}$ & $\begin{array}{l}\text { Migration/mobility as celebrating } \\
\text { youth } \\
- \text { mobility as a critical characteristic } \\
\text { for the phase of youth }\end{array}$ & Prolongation \\
\hline $\begin{array}{l}\text { Individualized model } \\
\text { of transition based on } \\
\text { economic autonomy }\end{array}$ & $\begin{array}{l}\text { Migration/mobility as a way to gain } \\
\text { adulthood } \\
\text { - mobility as a way of gaining financial } \\
\text { and personal resources for adulthood }\end{array}$ & Speeding up \\
\hline
\end{tabular}

Source: author's own elaboration.

If we consider the impact of migration or mobility experiences on the timing of transition the effect is differentiated. In the first model of transition, migration or mobility experiences seem to have little effect, or potentially speed up transitions. Some respondents who had certain experiences e.g. living outside the family home, had difficulties returning to the previous situation and aimed at moving out as soon as possible. Some of them gathered financial resources to gain more economic independence from their parents. In the third model, mobility was mostly used instrumentally to gain resources of diverse types and this usually had a speeding up effect. If mobility is utilized to celebrate youth, there is a strong possibility for the prolongation of the phase of youth. The social norm to "make the most out of your youth" [dobrze wykorzystać młodość] is not clear enough and this made some of the 
respondents or their partners fear the conclusion of this phase of life in a manner that would ensure no regrets later on. It is difficult for young adults to judge when they had accumulated enough youthful experiences.

The study results confirm other researchers' proposals for inclusion of mobility as an important aspect in studying youth transition. The presence of fluid migrants, intensively engaging in movement, suggests the need to study youth transitions in the context of detachment and de-rooting, where mobility choices are primary to other life decisions. While recent studies indicate a certain dilemma between rootedness and open attitude towards future mobility (Cuzzocrea 2018), this study shows that for some young people migration or mobility experience can be a single episode or event - an important element of their biography pragmatically used for realization of certain desires or motivations, not necessarily resulting in identity negotiations. We can as well see it as an element entering smoothly into the collection of memories in relation to the young age (as shown before, its lack creates a feeling of regret). This 'event', while having a role in the life-course as such, does not necessarily lead to further mobility or reevaluation of the location. Of course, for some of the respondents it seems that their mobility trajectory is not completed (or under evaluation), which corresponds to the fact that the spatial reflexivity is a trait of young European generations (Cairns 2014). This holds especially for those who live in the peripheries of Europe and are deemed to search better opportunities and higher quality of life in Western countries. In fact, the opening of European borders provided a wide plethora of opportunities for the studied cohort and my last comment relates to the importance of a generational perspective in studying the engagement of young people in mobility.

The described experience of exploiting going abroad opportunities and the social expectations of mobility are definitely particular for the studied boom generation. The intensive engagement of young people from the region in migration and mobility was studied by scholars both from the perspectives of sending and receiving countries, and in a way their experience constitutes a strong basis for theoretical debate on the new European youth mobility (King 2018). Younger generations of Poles (born after 1985) have different attitudes to mobility and migration as compared to the studied age cohort: as citizens of Europe by default, they do not assign such high a value to going abroad (Wrzesien 2009). Certain socio-cultural conditions of living of the cohort born around the 1980 caused both high engagement in mobility and migration, as well as a prolongation of youth transitions, thus making it an interesting case study for both migration scholars and youth researchers. While they are still under academic scrutiny from researchers who follow their migration trajectories, there is a need for including the younger cohorts in further studies to see the particularity of their experiences as linked to international movement. 


\section{SM̂PP}

\section{References}

Arnett, J.J. (2004), Emerging Adulthood. The Winding Road from the Late Teens through the Twenties, Oxford: Oxford University Press.

Billari, F.C. (2001), The analysis of early life courses: Complex descriptions of the transition to adulthood, "Journal of Population Research", vol. 8, iss. 2: 119-142.

Cairns, D. (2014), Youth Transitions, International Student Mobility and Spatial Reflexivity: Being Mobile?, Basingstoke: Palgrave Macmillan.

Cairns D., Growiec K., Smyth J. (2012), Spatial reflexivity and undergraduate transitions in the Republic of Ireland after the Celtic Tiger, "Journal of Youth Studies", vol. 15, iss. 7, pp. 841-857.

Cairns D., Krzaklewska E., Cuzzocrea V., Allaste A. (2018), Mobility, education and employability in the European Union, Basingstoke: Palgrave Macmillan.

Cuzzocrea V. (2018), 'Rooted mobilities' in young people's narratives of the future: A peripheral case, "Current sociology", Vol. 66, iss. 7, pp. 1106-1123.

Cuzzocrea V., Mandich G. (2016), Students' narratives of the future: Imagined mobilities as forms of youth agency?, "Journal of Youth Studies", vol. 19, issue 4, pp. 552-567.

Desperak, I., Śmiałek, J. (2010), Młodzi w Łodzi - prekariat z wyższym wykształceniem. Raport z badań 2010, Biblioteka Online Think Tanku Feministycznego. http://www.ekologiasztuka.pl/pdf/ f0099prekariat-lodz.pdf [Accessed: 10.03.2013]

Eade, J., Drinkwater, S., Garapich, M. (2006), Class and Ethnicity. Polish Migrants in London. Research Report for the RES-000-22-1294 ESRC project. Guildford: University of Surrey. https:// esrc-files.s3-eu-west-1.amazonaws.com/outputs/RxRVifuOKECMKwiqtrYCxA/ilklufjGjEipUq8QcH2Rw.pdf [Accessed: 27.07.2016].

Eurobarometer (2007),Young Europeans. Survey among young people aged between 15-30 in the European Union.Summary, http://ec.europa.eu/public_opinion/flash/fl_202_en.pdf [Accessed: 27.07.2016]

Eurostat (2012), Dashboard on Youth Indicators., http://ec.europa.eu/eurostat/web/youth/data/ eu-dashboard [Accessed: 19.09.2016]

Fihel, A., Kaczmarczyk, P., Okólski, M. (2007), Migracje "nowych Europejczyków” - teraz i przedtem, Warszawa: Wydawnictwo Uniwersytetu Warszawskiego.

FRSE (2012), Erasmus w Polsce. Polska w Erasmusie, Warszawa: FRSE, http://www.erasmus.org. pl/sites/erasmus.org. pl/files/publikacje/Erasmus\%20w\%20Polsce,\%20Polska\%20w\%20Erasmusie.\%20Publikacja\%20wydana\%20z\%20okazji\%2025-lecia\%20programu.pdf [Accessed: 01.08.2016].

Furlong, A., Cartmel, F. (2007), Young People and Social Change: New Perspectives, Buckingham: Open University Press.

Galland, O. (1996), Introduzione. Che cosa e' la gioventu?, in: A. Cavalli, O. Galland, Senza fretta di crescere. L'ingresso difficile nella vita adulta, Napoli: Liguori.

Grabowska-Lusinska, I. (ed.) (2010), Poakcesyjne powroty do Polski. "CMR Working Papers", No 43/(101). Warszawa. http://www.migracje.uw.edu.pl/wp-content/uploads/2016/11/ WP_43_101_IGL.pdf

Grabowska-Lusińska, I., Okólski, M. (2009), Emigracja ostatnia?, Warszawa: Scholar.

GUS (2013), Migracje zagraniczne ludności. Narodowy Spis Powszechny Ludności i Mieszkań 2011, Warszawa: Główny Urząd Statystyczny, http://stat.gov.pl/spisy-powszechne/nsp-2011/ nsp-2011-wyniki/migracje-zagraniczne-ludnosci-nsp-2011,13,1.html [Accessed: 31.07.2016] 
GUS (2011), Rocznik Demograficzny, Warszawa: Główny Urząd Statystyczny, http://stat.gov.pl/obszary-tematyczne/roczniki-statystyczne/roczniki-statystyczne/rocznik-demograficzny-2011,3,5. html [Accessed: 27.06.2016].

GUS (2010), Bank Danych Lokalnych, Warszawa: Główny Urząd Statystyczny.

Heinz, R. W. (2009), Youth transitions in an age of uncertainty, in: A. Furlong (ed.), Handbook of Youth and Young Adulthood. New perspectives and agendas, London-New York: Routledge.

Huang L., Krzaklewska E., Pustulka P. (2016). Young Polish Migrants in Norway: Education, work and settlement choice. "Tidsskrift for ungdomsforskning". Vol. 16, iss.1, pp. 63-78

King, R. (2018), Theorising New European Youth Mobilities. "Population, Space and Place" vol. 24, iss.1, e2117, https://doi.org/10.1002/psp.2117

King, R., Williams A.M. (2018), Editorial Introduction: New European Youth Mobilities. Population, Space and Place, vol. 24, iss.1, e2121.

Kotowska, I.E., Jóźwiak, J., Matysiak, A., Baranowska, A. (2008), Poland: Fertility decline as a response to profound societal and labour market changes? "Demographic Research", vol. 19, iss. 22, pp. 795-854.

Krzaklewska, E. (2016), Spory wokół koncepcji dorosłości. Nowe wzory kulturowe w Polsce [Debates around the concept of adulthood. New cultural patterns of adulthood in Poland], Doctoral thesis, Kraków: Uniwersytet Jagielloński.

Krzaklewska, E. (2014), Odrzucanie dorosłości czy nowa dorosłość? Dylematy i dyskusje w badaniu procesów wchodzenia w dorosłość. "Societas/Communitas”, vol. 18,iss.1-2, pp. 47-68.

Krzaklewska, E. (2013), ERASMUS Students between Youth and Adulthood: Analysis of the Biographical Experience, in: B. Feyen, E. Krzaklewska, The ERASMUS Phenomenon - Symbol of a New European Generation?, Frankfurt am Main: Peter Lang GmbH.

Krzaklewska, E. (2010), „Tak wiele się nauczyłam/em” - analiza doświadczenia wyjazdu na Erasmusa., in: D. Pauluk (ed.), Student na wspótczesnym uniwersytecie - ideały i codzienność, Kraków: Impuls.

Krzaklewska, E. (2009), The after-EU-accession emigration of youth in the light of the new cultural patterns of adulthood in Poland. "Forum21. European Journal on Child and Youth Research", No. 4 (December).

Okólski, M., Fihel, A. (2012), Demografia: współczesne zjawiska i teorie, Warszawa: Scholar. Miles, M.B, Huberman, M.A. (2000), Analiza danych jakościowych, Białystok: Trans Humana.

Piszczatowska-Oleksiewicz, M. (2014), Polscy gniazdownicy. O powodach, dla których dorosłe dzieci mieszkają z rodzicami. "Pogranicze. Studia Społeczne", vol. XXIV, pp. 181-207.

Ravert, D.R. (2009), 'You're Only Young Once': Things College Students Report Doing Now Before It Is Too Late. "Journal of Adolescent Research", vol. 24, iss. 3, pp. 376-396.

Robertson S., Harris A., Baldassar L. (2018), Mobile transitions: a conceptual framework for researching a generation on the move, "Journal of Youth Studies", vol. 21, iss. 2, pp. 203-217.

Ryan L. (2018), Differentiated embedding: Polish migrants in London negotiating belonging over time, "Journal of Ethnic and Migration Studies", vol. 44, iss. 2, pp. 233-251.

Settersten Jr., R.A. (2007), Passages to Adulthood: Linking Demographic Change and Human Development, "European Journal of Population", vol. 23, iss. 3, pp. 251-272.

Slany, K., Solga, B. (ed.), (2014), Społeczne skutki poakcesyjnych migracji ludności Polski, Warszawa: Komitet Badań nad Migracjami Polskiej Akademii Nauk, http://www.kbnm.pan.pl/images/ Raport_KBnM_PAN_Spo\%C5\%82eczne_skutki_poakcesyjnych_migracji_ludno\%C5\%9Bci_Polski.pdf [Accessed: 27.07.2016]. 
Slany, K. (2007), Alternatywne formy życia małżeńsko-rodzinnego. In: A. Kojder (ed.), Jedna Polska? Dawne i nowe zróżnicowania społeczne. Kraków: Wydawnictwo WAM, pp. 237-269.

Slany, K. (2006), Socjo-demograficzny „syndrom opóźniania” i jego konsekwencje dla polityki społecznej, in: A. Michalska (ed.), Obrazy życia rodzinnego z perspektywy interdyscyplinarnej (Seria: Roczniki Socjologii Rodziny), Poznań: Wydawnictwo Naukowe UAM, pp. 13-19. Slany, K. (2002), Alternatywne formy życia małżeńsko-rodzinnego w ponowoczesnym świecie, Kraków: Nomos.

Shanahan, M.J. (2000), Pathways to adulthood in changing societies: Variability and mechanisms in life course perspective, "Annual Review of Sociology", vol. 26, pp. 667-692.

Szafraniec, K. (2011), Młodzi 2011, Warszawa: Kancelaria Prezesa Rady Ministrów. http://zds.kprm. gov.pl/mlodzi-2011 [Accessed: 10.08.2013].

Szewczyk, A. (2015), European Generation of migration: Change and agency in the post-2004 Polish graduates' migratory experience, "Geoforum", iss. 60, pp.153-162.

White, A. (2014), Double Return Migration: Failed Returns to Poland Leading to Settlement Abroad and New Transnational Strategies, "International Migration", vol. 52, iss. 6, pp. 72-84.

Wrzesień, W. (2009), Europejscy Poszukiwacze. Impresje na temat wspótczesnego pokolenia polskiej młodzieży, Warszawa: Wydawnictwo Naukowe PWN. 